\title{
Odnos nekih demografskih i razrednih karakteristika te školske klime i socijalne podrške prema stresu učitelja
}

\author{
Maja Brust Nemet* \\ mbrust@foozos.hr \\ https://orcid.org/0000-0002-6936-3024 \\ Tena Velki*** \\ tvelki@foozos.hr \\ https://orcid.org/0000-0002-9529-8959
}

\author{
https://doi.org/10.31192/np.18.3.5 \\ UDK: 37.011.3-051:159.944.4 \\ 331.44:373.3 \\ Izvorni znanstveni rad / Original scientific paper \\ Primljeno: 24. lipnja 2020. \\ Prihvaćeno: 17. kolovoza 2020.
}

Stres učitelja sveprisutan je u školama, a učiteljeve demografske i razredne karakteristike te školska klima i socijalna podrška važni su za percepciju razine stresa. Cilj istraživanja bio je provjera povezanosti razine stresa s demografskim karakteristikama i karakteristikama razreda te sa školskom klimom $i$ socijalnom podrškom kod 311 hrvatskih učitelja razredne nastave. Učitelji su ispunili Skalu za mjerenje izvora nastavničkog stresa, Skalu socijalnih zaliha $i$ Upitnik školske klime te su dali demografske podatke i podatke o razrednom odjelu i školi u kojoj rade. Rezultati su pokazali da demografske karakteristike nisu značajne u odnosu na razinu stresa, ali se od razrednih karakteristika broj učenika u razrednom odjelu pokazao značajnim za doživljaj stresa. Utvrdilo se i da učitelji koji doživljavaju višu razinu ukupnog stresa $i$ višu razinu stresa uzrokovanog radnim opterećenjem $i$ potrebom za profesionalnim priznanjem doživljavaju školsku klimu negativnijom te je viša razina stresa povezana i sa slabijom socijalnom podrškom.

Ključne riječi: socijalna podrška, stres, škola, školska klima, učitelji.

\footnotetext{
* Doc. dr. sc. Maja Brust Nemet, Sveučilište Josipa Jurja Strossmayera u Osijeku, Fakultet za odgojne i obrazovne znanosti, Cara Hadrijana 10, HR-31000 Osijek.

**: Izv. prof. dr. sc. Tena Velki, Sveučilište Josipa Jurja Strossmayera u Osijeku, Fakultet za odgojne i obrazovne znanosti, Cara Hadrijana 10, HR-31000 Osijek.
} 


\section{Uvod}

Mnogobrojna su istraživanja utvrdila da je stres vrlo često prisutan među učiteljima. ${ }^{1}$ Stres i izgaranje na poslu učitelja povezani su s mnogim nepovoljnim ishodima za učitelje, učenike i cjelokupan odgojno-obrazovni sustav. ${ }^{2}$ Izgaranje na poslu (eng. burnout) rezultat je intenzivnog i dugotrajnog stresa na poslu s nedovoljno izvora zadovoljstva, a to rezultira iscrpljenošću, gubitkom motivacije i interesa za posao. ${ }^{3}$ Istraživanja su pokazala da su stres i izgaranje na poslu veće u državnim školama i u školama na urbanom području, gdje su zahtjevi visoki, a resursi mali, ${ }^{4}$ stoga neki autori istražuju uloge aktivnih i pasivnih strategija upravljanja stresom. ${ }^{5}$ Raspravlja se o učincima modela izravne podrške i modela koji štiti osobe od štetnih učinaka stresnih događaja. ${ }^{6}$ Učitelji koji s učenicima imaju kvalitetne odnose postižu više osobnog postignuća, dok su konfliktni odnosi s učenicima povezani s emocionalnom iscrpljenošću učitelja. ${ }^{7}$ Meta-analizom je utvrđeno da je učiteljevo izgaranje na poslu, odnosno emocionalna iscrpljenost i depersonalizacija, povezano s neprimjerenim ponašanjem učenika u razredu.

Osobna su postignuća učitelja negativno povezana s neprimjerenim ponašanjem učenika, dok emocionalna iscrpljenost učitelja može ometati učiteljevu sposobnost korištenja pozitivnih strategija upravljanja ponašanjem učenika. ${ }^{8}$ Učitelji srednjih škola, mlađi učitelji i učitelji koji rade u SAD-u pokazuju veću povezanost između neprimjerenog ponašanja učenika i emocionalne iscrpljenosti učitelja, kao i depersonalizacije. Demografske karakteristike i karakteristike škole pokazale su se ključnima za razinu stresa učitelja srednjih škola, odnosno učitelji koji rade u školama na gradskom području doživljavali su višu razinu

${ }^{1}$ Sve imenice koje imaju rodno značenje u ovom radu navode se u muškom rodu, a podjednako se odnose na muški i ženski rod. Imenica »učitelj « u radu se koristi i za imenicu »nastavnik«, a podrazumijeva sve učitelje i nastavnike koji rade u osnovnim i srednjim školama.

2 Usp. Keith C. HERMAN i dr., Profiles of middle school teacher stress and coping. Concurrent and prospective correlates, Journal of School Psychology, 78 (2020) 54-68; DOI: 10.1016/j. jsp.2019.11.003.

${ }^{3}$ Usp. Gregory MOORHEAD, Ricky W. GRIFFIN, Organizational behavior. Managing People and Organizations, Boston, Houghton Mifflin Company, 2004, 147-154.

${ }^{4}$ Usp. Jessika H. BOTTIANI i dr., Teacher stress and burnout in urban middle schools. Associations with job demands, resources, and effective classroom practices, Journal of School Psychology, 77 (2009) 36-51; DOI: 10.1016/j.jsp.2019.10.002.

${ }^{5}$ Usp. David W. CHAN, Stress, coping strategies, and psychological distress among secondary school teachers in Hong Kong, American Educational Research Journal, 35 (1998) 1, 145-163; DOI: $10.3102 / 00028312035001145$.

${ }^{6}$ Usp. Sheldon COHEN, Thomas A. WILLS, Stress, Social Support and the Buffering Hypothesis, Psychological Bulletin, 98 (1985) 2, 310-357; DOI: 10.1037/0033-2909.98.2.310.

7 Usp. Catherine M. CORBIN i dr., The role of teacher-student relationships in predicting teachers' personal accomplishment and emotional exhaustion, Journal of School Psychology, 77 (2019) 1-12; DOI: 10.1016/j.jsp.2019.10.001.

${ }^{8}$ Usp. Ariel M. ALOE i dr., A multivariate meta-analysis of student misbehavior and teacher burnout, Educational Research Review, 12 (2014) 30-44; DOI: 10.1016/j.edurev.2014.05.003. 
stresa zbog loših radnih uvjeta, loših odnosa unutar kolektiva i neprimjerenog ponašanja učenika, dok su učitelji na ruralnim područjima doživljavali loše radne uvjete i vremenske pritiske ključnima za visoku razinu stresa i izgaranje na poslu. ${ }^{9}$ Od razrednih karakteristika pokazalo se da razredni odjeli s manje od dvadeset učenika smanjuju zahtjeve radnog opterećenja i bolje zadovoljavaju potrebe učenika, kao i da inkluzivni razredni odjeli koji imaju učenika s teškoćama u razvoju povećavaju stres učitelja. ${ }^{10}$ Organizacijski čimbenici i vođenje ustanove su jako povezani s osjećajem stresa učitelja na svim razinama odgojno-obrazovnog sustava. ${ }^{11}$ Učiteljevo zanimanje karakterizira visoka razina sagorijevanja i emocionalne iscrpljenosti, a učitelji bi trebali što ranije saznati kako se aktiviraju i reguliraju vlastite emocije. ${ }^{12}$

Različiti izvori stresa i socijalna podrška značajni su prediktori školske klime. ${ }^{13}$ Viša razina stresa uzrokovanog neprimjernim ponašanjem učenika, manja razina stresa uzrokovana potrebom za profesionalnim priznanjem te percepcija veće socijalne podrške predviđaju pozitivniju školsku klimu. Socijalna se podrška učiteljima pokazala nužnom za smanjenje svih uzroka stresa, a zanimanje učitelja drugo je po izvoru stresa među istraženih dvadeset i šest zanimanja u Velikoj Britaniji. ${ }^{14}$

Stres učitelja povezan je sa školskom klimom na koju najviše utječe motivacija i ponašanje učenika. ${ }^{15}$ I obrnuto, učiteljevo sagorijevanje na poslu može utjecati na smanjenu motivaciju u učenika. ${ }^{16}$ Nadalje, pokazalo se da je percipirani stres učitelja uvjetovan ponašanjem učenika, odnosno što je učinkovitije poučavanje to je veće zadovoljstvo poslom i manja je percepcija stresa. Štoviše, nije utvrđena statistički značajna razlika između procjena učitelja razredne i predmetne nastave kad je u pitanju percepcija uvjeta na poslu kao izvora stresa

${ }^{9}$ Usp. Millicent H. ABEL, Joanne SEWELL, Stress and burnout in rural and urban secondary school teachers, Journal of Educational Research, 92 (1999) 5, 287-293; DOI: 10.1080/00220679909597608.

${ }^{10}$ Usp. Lynda J. YOUNGHUSBAND, High school teachers' perceptions of their working environment in Newfoundland. A grounded theory study, doktorska disertacija, Newfoundland and Labrador, Faculty of Medicine, University of Newfoundland, 2005, 95-100.

${ }^{11}$ Usp. Barbara M. BYRNE, Burnout. Investigating the impact of background variables for elementary, intermediate, secondary, and university educators, Teaching and Teacher Education, 7 (1991) 2, 197-209; DOI: 10.1016/0742-051X(91)90027-M.

${ }^{12}$ Usp. Mei-Lin CHANG, An appraisal perspective of teacher burnout. Examining the emotional work of teachers, Educational Psychology Review, 21 (2009) 3, 193-218; DOI: 10.1007/s10648009-9106-y.

${ }^{13}$ Usp. Maja BRUST NEMET, Tena VELKI, Some demographic, personal and class characteristics as predictors of school climate, Education and New Development, 1 (2019) 17-21.

${ }^{14}$ Usp. Sheena JOHNSON i dr., The experience of work-related stress across ocupations, Journal of Managerial Psychology, 20 (2005) 2, 178-187.

${ }^{15}$ Usp. Rebecca J. COLLIE, Jennifer D. SHAPKA, Nancy E. PERRY, School Climate and SocialEmotional Learning: Predicting Teacher Stress, Job Satisfaction, and Teaching Efficacy, Journal of Educational Psychology, 104 (2012) 4, 1189-1204.

${ }^{16}$ Usp. Bo SHEN i dr., The relationship between teacher burnout and student motivation, British Journal of Educational Psychology, 85 (2015) 4, 519-532; DOI: 10.1111/bjep.12089. 
ni kad su u pitanju odnosi na poslu. Učiteljevo zadovoljstvo životom ili poslom veće je ako je veća usmjerenost na problem, a manje što je veća usmjerenost na emocije i pri tome je nesigurnost u sebe i svoje postupke veća te učitelji nisu spremni na stresne situacije. ${ }^{17}$

Stres učitelja sveprisutan je u školama, uvjetovan je psihološkim i fizičkim stresorima, a manifestira se emocionalnim, kognitivnim simptomima i simptomima u ponašanju. Što su učitelji zadovoljniji uvjetima u kojima rade veća je vjerojatnost da će razina stresa biti niža, stoga je važno identificirati ono što je povezano sa stresom hrvatskih učitelja. U ovom će se istraživanju utvrditi odnos demografskih (regija Hrvatske u kojoj rade učitelji, godine radnog staža, osnovna i viša zvanja) i razrednih karakteristika (veličina razrednog odjela $u$ kojem rade i broj učenika s teškoćama u razvoju) te školske klime i socijalne podrške koju je moguće mijenjati u odgojno-obrazovnom kontekstu.

\section{Metodologija istraživanja}

\subsection{Cilj istraživanja}

Cilj istraživanja bio je dvostruk: 1. provjeriti postojanje razlike u razini različitih izvora stresa u odnosu na demografske karakteristike učitelja (regija Hrvatske iz koje učitelji dolaze, godine radnog staža, posjeduju li učitelji osnovna ili viša zvanja) i razredne karakteristike (veličina razrednog odjela u kojem rade te imaju li u svom razrednom odjelu učenika s teškoćama u razvoju); 2. provjeriti povezanost razine stresa sa školskom klimom i socijalnom podrškom kod učitelja razredne nastave.

Stres je utvrđivan pomoću Skale za mjerenje izvora nastavničkog ${ }^{18}$ stresa $^{19}$ te je ona mjerila opću razinu učiteljevog stresa i tri izvora stresa kod učitelja: neprimjereno ponašanje učenika (koliko učeničko neprimjereno ponašanje ometa rad učitelja i izaziva stres), potrebu za profesionalnim priznanjem (koliko potreba za profesionalnim priznanjem, istovremeno, djelomično ili potpuno neostvarenje te potrebe izaziva stres) i radno opterećenje (koliko pretjerana opterećenost učitelja izaziva stres).

Od demografskih karakteristika provjeravala se regija Hrvatske u kojoj rade učitelji (središnja Hrvatska, sjeverozapadna Hrvatska, istočna Hrvatska,

\footnotetext{
${ }^{17}$ Usp. Ivica BRKIĆ, Majda RIJAVEC, Izvori stresa, suočavanje sa stresom i životno zadovoljstvo učitelja razredne i predmetne nastave, Napredak, 152 (2012) 2, 211-225.

${ }^{18}$ Imenica »nastavnik« koristi se u izvornoj Skali za mjerenje izvora nastavničkog stresa i Upitniku školske klime - verzija za nastavnike koje su u slučaju ovoga rada korištene i među učiteljima razredne nastave.

${ }^{19}$ Usp. Izabela SORIĆ, Ivana MIKULANDRA, Skala za mjerenje izvora nastavničkog stresa, u: Ana PROROKOVIĆ i dr. (ur.), Zbirka psihologijskih skala i upitnika, sv. 2, Zadar, Sveučilište u Zadru, 2004, 62-69.
} 
sjeverni Jadran i Lika, srednji i južni Jadran), godine radnog staža (manje od 15 godina, između 15 i 25 godina i više od 25 godina radnog staža) te posjeduju li osnovna ili viša zvanja. Osnovna zvanja podrazumijevaju diplomirane učitelje i magistre primarnog obrazovanja, a viša zvanja da uz osnovna zvanja imaju izbor u viša stručna zvanja (mentor ili savjetnik) ili viša znanstvena zvanja (magisterij ili doktorat znanosti).

Razredne karakteristike obuhvaćale su veličinu razreda (veliki razredi s 21 do 30 učenika, razredi srednje veličine s 10 do 20 učenika i mali razredi s manje od 20 učenika) te ima li u razrednom odjelu učenika s teškoćama.

Školska klima mjerena je među učiteljima putem Upitnika školske klime verzija za nastavnike ${ }^{20}$ te utvrđuje opću dimenziju školske klime, dok je socijalna podrška mjerena pomoću Skale socijalnih zaliha ${ }^{21}$ koja utvrđuje opću percepciju socijalne podrške dostupne pojedincu.

\subsection{Istraživačke hipoteze}

U skladu s prvim ciljem istraživanja za provjeru razlika u demografskim karakteristikama učitelja te za provjeru razlika u karakteristikama razrednog odjela postavljene su sljedeće hipoteze:

1. Učitelji iz različitih regija Hrvatske neće se razlikovati u razini općeg stresa kao ni u razinama svih triju izvora stresa (neprimjereno ponašanje učenika, potreba za profesionalnim priznanjem, radno opterećenje);

2. Učitelji s više radnog staža percipirat će višu razinu općeg stresa kao i različitih izvora stresa (neprimjereno ponašanje učenika, potreba za profesionalnim priznanjem, radno opterećenje);

3. Učitelji s višim stručnim ili znanstvenim zvanjima percipirat će manju razinu općeg stresa kao i različitih izvora stresa (neprimjereno ponašanje učenika, potreba za profesionalnim priznanjem, radno opterećenje);

4. Učitelji koji rade u većim razrednim odjelima percipirat će višu razinu općeg stresa kao i različitih izvora stresa (neprimjereno ponašanje učenika, potreba za profesionalnim priznanjem, radno opterećenje);

5. Učitelji koji u svom razrednom odjelu imaju učenike s teškoćama percipirat će višu razinu općeg stresa kao i različitih izvora stresa (neprimjereno ponašanje učenika, potreba za profesionalnim priznanjem, radno opterećenje).

\footnotetext{
${ }^{20}$ Usp. Tena VELKI, Provjera ekološkoga modela dječjega nasilničkoga ponašanja prema vršnjacima, doktorska disertacija, Zagreb, Filozofski fakultet, Sveučilište u Zagrebu, 2012, 66.

${ }^{21}$ Usp. Marina NEKIĆ, Skala socijalnih zaliha, u: Vera ĆUBELA ADORIĆ i dr. (ur.), Zbirka psihologijskih skala $i$ upitnika, sv. 4, Zadar, Sveučilište u Zadru, 2008, 49-58.
} 
U skladu s drugim ciljem istraživanja postavljene su dodatne hipoteze:

1. Pretpostavlja se da je viša razina općeg stresa kao i svih triju izvora stresa (neprimjereno ponašanje učenika, potreba za profesionalnim priznanjem, radno opterećenje) povezana s percepcijom negativnije školske klime;

2. Pretpostavlja se da je viša razina općeg stresa kao i svih triju izvora stresa (neprimjereno ponašanje učenika, potreba za profesionalnim priznanjem, radno opterećenje) povezana s percepcijom manje socijalne podrške.

\subsection{Sudionici istraživanja}

U istraživanju je sudjelovalo 311 učitelja razredne nastave $(97,7$ \% ženskog spola) iz svih županija Republike Hrvatske, pri čemu ih je najviše bilo iz istočne Hrvatske (57,4\%). Većina ih je imala više od 41 godine života $(61,6 \%)$ te više od 15 godina radnog staža (68,6 \%). Uzorak je bio prigodan, sudionici istraživanja su ujedno bili i sudionici Državnog stručnog skupa učitelja razredne nastave.

\subsection{Instrumenti istraživanja}

Skala za mjerenje izvora nastavničkog stresa ${ }^{22}$ utvrđuje opći izvor radnog stresa kod učitelja. Sastoji se od 25 tvrdnji, a učitelji trebaju iskazati svoje slaganje na skali Likertovog tipa s pet stupnjeva. Pri tom 1 znači »uopće nije stresno«, a 5 »vrlo jako stresno«. Skala za mjerenje izvora nastavničkog stresa može se podijeliti i na tri supskale koje utvrđuju različite izvore stresa: Neprimjereno ponašanje učenika $(\mathrm{k}=6)$, Potreba za profesionalnim priznanjem $(\mathrm{k}=12)$ i Radno opterećenje $(\mathrm{k}=7)$. Ukupan rezultat dobiva se na temelju aritmetičke sredine svih čestica te se teoretski kreće od 1 do 5 , a rezultati za supskale dobivaju se na temelju aritmetičke sredine odabranih čestica i teoretski se kreću od 1 do 5 . Pouzdanost Skale za mjerenje izvora nastavničkog stresa u ovom istraživanju iznosila je Cronbach $\alpha=0,91$, dok je za pojedine supskale iznosila Neprimjereno ponašanje učenika $\alpha=0,80$, Potreba za profesionalnim priznanjem $\alpha=0,84$ te Radno opterećenje $\alpha=0,74$.

Skala socijalnih zaliha ${ }^{23}$ mjeri opću percepciju socijalne podrške dostupne pojedincu, odnosno trenutne odnose s važnim osobama (npr. prijatelji, članovi obitelji, radni kolege, ali ne specificira niti jedan konkretan odnos). Sastoji se od 24 tvrdnje, a odgovori se daju na skali Likertovog tipa s 4 stupnja, pri čemu 1 označava »u potpunosti se slažem«, a 4 »u potpunosti se ne slažem«. Ukupan

\footnotetext{
${ }^{22}$ Usp. Sorić, Mikulandra, Skala za mjerenje izvora ..., 62-69.

${ }^{23}$ Usp. Nekić, Skala socijalnih zaliha..., 49-58.
} 
rezultat dobiva se na temelju aritmetičke sredine svih čestica te se teoretski kreće od 1 do 4. Pouzdanost Skale socijalnih zaliha u ovom istraživanju iznosila je Cronbach $\alpha=0,89$.

Upitnik školske klime - verzija za nastavnike (UŠK - verzija za nastavnike $)^{24}$ mjeri globalnu dimenziju školske klime koja uključuje odnos učenika i učitelja te odnos među djelatnicima škole, osjećaj pripadnosti školi, atmosferu učenja, roditeljsku uključenost u školu, predviđanje budućnosti učenika na temelju školovanja, kao i profesionalni razvoj. Sastoji se od 18 tvrdnji za koje učitelji trebaju iskazati svoje slaganje na skali Likertovog tipa s pet stupnjeva. Pri tom 1 znači »u potpunosti se slažem«, a 5 »uopće se ne slažem«. Ukupan rezultat dobiva se na temelju aritmetičke sredine svih čestica, te se teoretski kreće od 1 do 5 . Pouzdanost $U \check{S} K$ - verzije za nastavnike u ovom istraživanju iznosila je Cronbach $\alpha=0,88$.

\subsection{Postupak istraživanja}

Prikupljanje podataka odvijalo se za vrijeme trajanja Državnog stručnog skupa učitelja razredne nastave Jačanje profesionalnih kompetencija učitelja razredne nastave koji se održavao od 19. do 21. lipnja 2017. godine u Osijeku. Podaci su prikupljeni grupno, a popunjavanje upitnika u prosjeku je trajalo oko 20 minuta. Svi su pitani sudionici pristali popuniti upitnike. Istraživanje je bilo potpuno dobrovoljno i anonimno.

\section{Rezultati istraživanja}

U tablici 1. prikazane su karakteristike sudionika istraživanja. Učiteljica je bilo $97,7 \%$, dok je učitelja bilo svega $2,3 \%$. Većina ih je imala više od 41 godine života (61,6 \%). Gotovo polovica (48,2 \%) učitelja u svom razrednom odjelu imala je jedno ili više djece $s$ teškoćama u razvoju.

U tablici 2. prikazani su deskriptivni podaci za mjerene varijable. Testiranja normalnosti distribucija pokazala su da raspodjele glavnih istraživačkih varijabli ne odstupaju značajno od normalne distribucije. Indeksi asimetrija nisu prelazili vrijednosti veće od $-/+2,00$, a budući da su distribucije asimetrične na istu stranu odlučili smo se za parametrijsku statistiku. ${ }^{25}$

\footnotetext{
${ }^{24}$ Usp. Velki, Provjera ekološkoga modela..., 66.

${ }^{25}$ Usp. Andy FIELD, Discovering statistics using SPSS (and sex and drugs and rock ' $n$ ' roll), London, Sage publications, 2009, 185.
} 
Tablica 1. Karakteristike učitelja koji su sudjelovali u istraživanju (N=311)

\begin{tabular}{|l|c|c|c|c|c|c|c|}
\hline \multicolumn{1}{|c|}{ regija } & $\%$ & radni staž & $\mathbf{\%}$ & $\begin{array}{c}\text { veličina } \\
\text { razrednog } \\
\text { odjela }\end{array}$ & $\%$ & zvanja & $\%$ \\
\hline $\begin{array}{l}\text { Središnja } \\
\text { HR }\end{array}$ & $22,6 \%$ & $\begin{array}{c}\text { manje od } \\
15 \text { godina }\end{array}$ & $31,4 \%$ & $\begin{array}{c}\text { veliki (21 do } \\
30 \text { učenika) }\end{array}$ & $33,2 \%$ & $\begin{array}{c}\text { viša zvanja (stručna } \\
\text { (mentor, savjetnik), } \\
\text { znanstvena } \\
\text { (magistar, doktor } \\
\text { znanosti) }\end{array}$ & $45,2 \%$ \\
\hline $\begin{array}{l}\text { Sjeveroza- } \\
\text { padna HR }\end{array}$ & $6,9 \%$ & $\begin{array}{c}\text { između } 15 \\
\text { i } 25 \text { godina }\end{array}$ & $37,9 \%$ & $\begin{array}{c}\text { srednji } \\
\text { učenika) }\end{array}$ & $51,3 \%$ & $\begin{array}{c}\text { osnovna zvanja } \\
\text { (diplomirani učitelj, } \\
\text { magistar primarnog } \\
\text { obrazovanja) }\end{array}$ & $54,8 \%$ \\
\hline Istočna HR & $57,4 \%$ & $\begin{array}{c}\text { više od } 25 \\
\text { godina }\end{array}$ & $30,7 \%$ & $\begin{array}{c}\text { mali }(<10 \\
\text { učenika) }\end{array}$ & $15,5 \%$ & & \\
\hline $\begin{array}{l}\text { Jadran i } \\
\text { Lika }\end{array}$ & $5,6 \%$ & & & & & & \\
\hline $\begin{array}{l}\text { Srednji } \\
\text { i južni } \\
\text { Jadran }\end{array}$ & $7,5 \%$ & & & & & & \\
\hline
\end{tabular}

Tablica 2. Deskriptivni podaci za mjerene varijable $(\mathrm{N}=311)$

\begin{tabular}{|l|c|c|c|c|c|c|}
\hline \multicolumn{1}{|c|}{ varijable } & Min & Max & M & SD & asimetričnost & spljoštenost \\
\hline školska klima & 2,17 & 5,00 & 4,07 & 0,428 & $-0,500$ & 1,286 \\
\hline učiteljski stres & 1,20 & 4,64 & 3,04 & 0,587 & $-0,187$ & 0,252 \\
\hline $\begin{array}{l}\text { neprimjereno } \\
\text { ponašanje učenika }\end{array}$ & 1,00 & 4,83 & 3,05 & 0,758 & $-0,295$ & $-0,121$ \\
\hline $\begin{array}{l}\text { potreba za } \\
\text { profesionalnim } \\
\text { priznanjem }\end{array}$ & 1,27 & 4,82 & 3,03 & 0,599 & 0,001 & 0,290 \\
\hline radno opterećenje & 1,14 & 4,57 & 3,10 & 0,662 & $-0,162$ & $-0,285$ \\
\hline socijalna podrška & 2,00 & 4,00 & 3,48 & 0,379 & $-0,895$ & 0,438 \\
\hline
\end{tabular}

Da bismo provjerili koje demografske karakteristike i karakteristike razreda potencijalno djeluju na stres u učitelja razredne nastave proveli smo niz ANOVA. Pri tome smo testirali razlike u razini različitih izvora stresa u odnosu na regiju Hrvatske iz koje učitelji dolaze, godine radnog staža, posjeduju li viša zvanja, koliko imaju učenika u razrednom odjelu te imaju li u svom razrednom odjelu učenika s teškoćama u razvoju.

Demografske varijable nisu se pokazale statistički značajne ni za jedan izvor stresa. Učitelji percipiraju iste razine stresa neovisno iz koje regije dolaze, koliko godina radnog staža imaju te posjeduju li viša zvanja ili ne (tablica 3).

Statistički značajne razlike u odnosu na veličinu razrednog odjela dobivene su za ukupni stres $\left(\mathrm{F}_{(2,309)}=3,29, \mathrm{p}<0,05\right)$ te neprimjereno ponašanje učenika 
Tablica 3. Testiranje razlika u razini različitih izvora stresa u odnosu na demografske karakteristike učitelja $(\mathrm{N}=311)$

\begin{tabular}{|c|c|c|c|c|c|}
\hline \multicolumn{2}{|l|}{ F / Varijable } & \multirow{2}{*}{$\begin{array}{l}\text { učiteljski } \\
\text { stres }\end{array}$} & \multirow{2}{*}{$\begin{array}{c}\text { neprimjereno } \\
\text { ponašanje } \\
\text { učenika }\end{array}$} & \multirow{2}{*}{$\begin{array}{c}\text { potreba za } \\
\text { profesionalnim } \\
\text { priznanjem }\end{array}$} & \multirow{2}{*}{$\begin{array}{l}\text { radno } \\
\text { opterećenje }\end{array}$} \\
\hline regija & $\%$ & & & & \\
\hline Središnja HR & $22,6 \%$ & \multirow{5}{*}{$\begin{array}{c}\mathrm{F}_{(4,307)}=0,35 \\
\mathrm{p}>0,01\end{array}$} & \multirow{5}{*}{$\begin{array}{c}\mathrm{F}_{(4,307)}=1,77 \\
\mathrm{p}>0,01\end{array}$} & \multirow{5}{*}{$\begin{array}{c}\mathrm{F}_{(4,307)}=0,42 \\
\mathrm{p}>0,01\end{array}$} & \multirow{5}{*}{$\begin{array}{c}F_{(4,307)}=0,65 \\
p>0,01\end{array}$} \\
\hline Sjeverozapadna HR & $6,9 \%$ & & & & \\
\hline Istočna HR & $57,4 \%$ & & & & \\
\hline Jadran i Lika & $5,6 \%$ & & & & \\
\hline Srednji i južni Jadran & $7,5 \%$ & & & & \\
\hline radni staž & $\%$ & & & & \\
\hline manje od 15 godina & $31,4 \%$ & \multirow{3}{*}{$\begin{array}{c}\mathrm{F}_{(2,309)}=2,03 \\
\mathrm{p}>0,01\end{array}$} & \multirow{3}{*}{$\begin{array}{c}\mathrm{F}_{(2,309)}=0,69 \\
\mathrm{p}>0,01\end{array}$} & \multirow{3}{*}{$\begin{array}{c}\mathrm{F}_{(2,309)}=2,64 \\
\mathrm{p}>0,01\end{array}$} & \multirow{3}{*}{$\begin{array}{c}\mathrm{F}_{(2,309)}=1,61 \\
\mathrm{p}>0,01\end{array}$} \\
\hline između 15 i 20 godina & $37,9 \%$ & & & & \\
\hline više od 25 godina & $30,7 \%$ & & & & \\
\hline zvanja & $\%$ & & & & \\
\hline viša zvanja & $45,2 \%$ & \multirow{2}{*}{$\begin{array}{c}F_{(1,310)}=0,30 \\
p>0,01\end{array}$} & \multirow{2}{*}{$\begin{array}{c}F_{(1,310)}=0,07 \\
p>0,01\end{array}$} & \multirow{2}{*}{$\begin{array}{c}\mathrm{F}_{(1,310)}=1,06 \\
\mathrm{p}>0,01\end{array}$} & \multirow{2}{*}{$\begin{array}{c}\mathrm{F}_{(1,310)}=0,84 \\
\mathrm{p}>0,01\end{array}$} \\
\hline osnovna zvanja & $54,8 \%$ & & & & \\
\hline
\end{tabular}

$\left(\mathrm{F}_{(2,309)}=7,80, \mathrm{p}<0,01\right)$. Post hoc analiza uz Games-Howellovu korekciju pokazala je da učitelji koji rade u malim razrednim odjelima (manje od 10 učenika) doživljavaju statistički značajno manje ukupnog stresa u odnosu na učitelje koji rade u velikim razrednim odjelima (21 do 30 učenika). Također statistički značajno manje stresa uzrokovanog neprimjerenim ponašanjem učenika doživljavaju učitelji koji rade $u$ malim razrednim odjelima $u$ odnosu na učitelje koji rade u razrednim odjelima srednje veličine (10 do 20 učenika) i velikim razrednim odjelima ( 21 do 30 učenika). Na ostalim varijablama stresa nije pronađena statistički značajna razlika, potreba za profesionalnim priznanjem $\left(\mathrm{F}_{(2,309)}=0,90, \mathrm{p}>0,01\right)$, radno opterećenje $\left(\mathrm{F}_{(2,309)}=2,87, \mathrm{p}>0,01\right)$.

U gotovo polovici razrednih odjela $(48,2 \%)$ nastavu je pohađalo jedno ili više djece s teškoćama u razvoju. Međutim ni na jednoj varijabli stresa nisu dobivene statistički značajne razlike $u$ odnosu na to ima li učitelj u svom razrednom odjelu djecu s teškoćama u razvoju, ukupni stres $\left(\mathrm{F}_{(1,310)}=0,01, \mathrm{p}>0,01\right)$, neprimjereno ponašanje učenika $\left(\mathrm{F}_{(1,310)}=1,25, \mathrm{p}>0,01\right)$, potreba za profesionalnim priznanjem $\left(\mathrm{F}_{(1,310)}=0,05, \mathrm{p}>0,01\right)$, radno opterećenje $\left(\mathrm{F}_{(1,310)}=0,13, \mathrm{p}>0,01\right)$.

Također se željela provjeriti povezanost razine stresa sa školskom klimom i socijalnom podrškom učitelja, pri čemu se pretpostavilo da će viša razina stresa biti statistički značajno povezana s percepcijom negativnije školske klime i percepcijom manje socijalne podrške. Radi toga izračunani su Pearsonovi koeficijenti korelacije (tablica 4). Dobiveni rezultati su u očekivanom smjeru, odnosno viša razina ukupnog stresa te viša razina stresa izazvana radnim opterećenjem i potrebom za profesionalnim priznanjem povezana je s negativnijom školskom klimom. Učitelji koji doživljavaju više stresa, odnosno veće optereće- 
nje i veću potrebu za profesionalnim priznanjem, doživljavaju i školsku klimu negativnijom. Također je viša razina ukupnog stresa te viša razina potrebe za profesionalnim priznanjem povezana sa slabijom socijalnom podrškom. Učitelji koji doživljavaju više stresa, odnosno imaju veću potrebu za profesionalnim priznanjem, ujedno i percipiraju da imaju manju socijalnu podršku okoline.

Tablica 4. Povezanost varijabli stresa sa školskom klimom i socijalnom podrškom

\begin{tabular}{|l|c|c|}
\hline \multicolumn{1}{|c|}{ varijable } & školska klima & socijalna podrška \\
\hline učiteljski stres & $-0,163^{* * *}$ & $-0,135^{*}$ \\
\hline neprimjereno ponašanje učenika & 0,020 & $-0,024$ \\
\hline potreba za profesionalnim priznanjem & $-0,247^{\text {*** }}$ & $-0,186^{* *}$ \\
\hline radno opterećenje & $-0,155^{\text {s* }}$ & $-0,103$ \\
\hline
\end{tabular}

" $\mathrm{p}>0,05 ;{ }^{* * *} \mathrm{p}>0,01$

\section{Rasprava}

Rezultati su istraživanja pokazali da se demografske karakteristike učitelja nisu pokazale značajne u odnosu na razinu stresa kojeg hrvatski učitelji doživljavaju na poslu, što znači da nema razlika u razini stresa u odnosu na regiju Republike Hrvatske u kojoj rade, na radni staž ili na viša zvanja. Za razliku od rezultata u provedenom istraživanju, neka druga istraživanja, ${ }^{26}$ pokazala su da postoje statistički značajne razlike između demografskih karakteristika i razine stresa, a osobito se to odnosilo na podatak rade li u državnim ili privatnim školama te školama koje se nalaze u urbanim ili ruralnim sredinama. Utvrdio se i veći intenzitet stresa kod učitelja s osnovnim zvanjima, što se objašnjava manjom razinom kontrole i autonomije, nižim prihodima i većom nesigurnošću posla. ${ }^{27}$ Može se pretpostaviti da rezultati ovoga istraživanja nisu u skladu s prijašnjima jer učitelji razredne nastave u Republici Hrvatskoj, bez obzira na radni staž, napredovanje i geografsku regiju u kojoj rade, imaju ujednačene uvjete rada s obzirom da većina učitelja radi u osnovnim školama čiji su osnivači gradovi i županije. Također imaju ujednačene kompetencije koje su uglavnom stekli tijekom studija u Republici Hrvatskoj, kao i slične mogućnosti što se tiče stručnog ili znanstvenog napredovanja, za razliku od prethodnih inozemnim istraživanja u kojima se znatnije razlikuju uvjeti rada među školama jer je puno veći broj privatnih škola i škola prema različitim alternativnim koncepcijama.

\footnotetext{
${ }^{26}$ Usp. Abel, Sewell, Stress and burnout in rural..., 287-290; Aloe i dr., A multivariate metaanalysis of student misbehavior and teacher burnout, Educational Research Review, 12 (2014) 30-44; DOI: 10.1016/j.edurev.2014.05.003; Bottiani i dr., Teacher stress and burnout..., 36-39.

${ }^{27}$ Usp. Ana SLIŠKOVIĆ, Stres kod nastavnika u visokom obrazovanju, Psihologijske teme, 20 (2011) 1, 67-90.
} 
S obzirom da se demografske karakteristike nisu pokazale statistički značajne za razinu stresa koju učitelji doživljavaju, bilo je potrebno provjeriti druge potencijalne varijable koje su se u prijašnjim istraživanjima pokazale povezanima s razinom stresa ${ }^{28}$ a to su razredne karakteristike te socijalna podrška.

Razredne karakteristike, kao što je veličina razrednog odjela, pokazale su se važnima za razinu stresa tako da učitelji u manjim (do 10 učenika) i srednjim (10-20 učenika) razrednim odjelima doživljavaju manje stresa u odnosu na velike razredne odjele (21-30 učenika). U istraživanju ETUC - European Trade Union Committee for Education ${ }^{29}$ također se utvrdilo da je uzrok stresa, osim nedostatka financijskih sredstava, lošeg društvenog statusa učitelja, nesigurnosti zaposlenja i nemogućnosti napredovanja, i prevelik broj učenika u razrednom odjelu. Također su naveli da su najčešći indikatori stresa kod učitelja bili bolovanja, problemi sa spavanjem i hipertenzija. Prema podatcima statističkog ureda Europskih zajednica - EUROSTAT ${ }^{30}$ prosječno je 2017. godine u Europi bilo 14,7 učenika po učitelju, dok je u Republici Hrvatskoj 14,6 učenika po učitelju, što je optimalno za rad, dok više od 20 učenika u pojedinom razrednom odjelu izaziva stres kod učitelja. Ne smijemo zanemariti činjenicu da je broj hrvatskih učenika po razrednom odjelu neujednačen u Republici Hrvatskoj. Broj učenika je veći u školama na urbanim područjima u odnosu na ruralna područja, a s druge strane većina škola Republike Hrvatske ima stalnu tendenciju smanjenja broja učenika zbog sve manjeg broja rođenih i sve većeg iseljavanja stanovništva iz Republike Hrvatske.

$\mathrm{U}$ provedenom istraživanju nije dobivena statistički značajna razlika u razini stresa s obzirom na to imaju li učitelji učenika s teškoćama u razvoju u razrednom odjelu. Među australskim učiteljima ${ }^{31}$ utvrđena je visoka razina stresa izazvana ometajućim ponašanjima učenika s teškoćama u razvoju u situacijama kada učitelji nisu dovoljno upoznati s obilježjima pojedinih teškoća u razvoju. U istraživanjima u SAD-u i Kanadi ${ }^{32}$ najučinkovitijim su se učiteljima pokazali oni koji uspješno promiču inkluziju, uključuju u više stupnjeve razmišljanja, reagiranja i dijaloške interakcije sve učenike, bez obzira imaju li neku teškoću u razvoju. S obzirom da su učinkoviti, vjerojatno su zadovoljniji svojim poslom

\footnotetext{
${ }^{28}$ Usp. Brust Nemet, Velki, Some demographic, personal and class...; Ronald J. BURKE, Esther R. GREENGLASS, Ralf SCHWARZER, Predicting teacher burnout over time. Effects of work stress, social support, and self-doubts on burnout and its consequences, Anxiety, Stress and Coping, 9 (1996) 3, 261-275; DOI: 10.1080/10615809608249406; Byrne, Burnout, Investigating the impact of background..., 197.

${ }^{29}$ Usp. Billehøj, Report on the ETUCE Survey...

${ }^{30}$ Usp. EUROSTAT, 15 pupils per teacher in EU primary schools (2019), https://ec.europa.eu/ eurostat/en/web/products-eurostat-news/-/DDN-20190911-1 (01.01.2019).

${ }^{31}$ Usp. Chris FORLIN, Inclusion: identifying potential stressors for regular class teachers, Educational Research, 43 (2001) 3, 235-245.

${ }^{32}$ Usp. Anne JORDAN, Christine GLENN, Donna MCGHIE-RICHMOND, The Supporting Effective Teaching (SET) project: The relationship of inclusive teaching practices to teachers' beliefs about disability and ability, and about their roles as teachers, Teaching and Teacher Education, 26 (2010) 2, 259-266; DOI: 10.1016/j.tate.2009.03.005.
} 
i time percipiraju nižu razinu stresa. $U$ ovom su se istraživanju hrvatski učitelji razredne nastave pokazali spremnima za inkluziju i vjerojatno imaju dovoljno kompetencija za rad s djecom s teškoćama u razvoju jer se nisu pokazale razlike u razini stresa s obzirom na to imaju li ili ne učenika s teškoćama u razvoju $\mathrm{u}$ svom razrednom odjelu. Možda bi se uočile razlike u istraživanjima razine stresa među učiteljima predmetne nastave, što se planira istražiti u budućim istraživanjima.

Učitelji koji doživljavaju višu razinu ukupnog stresa i višu razinu stresa uzrokovanog radnim opterećenjem i potrebom za profesionalnim priznanjem doživljavaju i školsku klimu negativnijom. Očekivano je da se ne osjećaju dobro u uvjetima koji im uzrokuju stres, odnosno klimom koja ih ni ne motivira niti podržava, s prevelikim radnim opterećenjem, posebice administrativnim, kao i nedostatnom socijalnom podrškom okoline u profesionalnom razvoju. Školska klima koju karakterizira učinkovito vođenje, kolegijalnost među sustručnjacima i jačanje profesionalizma pomaže u smanjenu stresa, ${ }^{33}$ stoga se predlaže ravnateljima da razmotre čimbenike školske klime da bi ih mogli poboljšati, a time i smanjiti stres učitelja. ${ }^{34} \mathrm{U}$ istraživanjima ${ }^{35}$ je dokazano da se sa školskom klimom povezuje učiteljev doživljaj stresa i podrške. Utvrđena je povezanost između socijalnih, pedagoških kompetencija učitelja i školske kulture. Kvaliteta komunikacije, suradnje i kolegijalnosti ima snažan utjecaj na školsku kulturu, a time i školsku klimu. ${ }^{36}$ Rezultati istraživanja pokazuju da učitelji percipiraju manju socijalnu podršku okoline te je utvrđena i visoka povezanost percepcija učitelja o socijalnoj podršci s izgaranjem na poslu, jednako kao i u istraživanju među hrvatskim učiteljima. ${ }^{37}$ Longitudinalnim istraživanjem utvrđeno je da su administrativni poslovi učitelja, ometajuća ponašanja učenika i nedostatna podrška supervizora značajno povezani s izgaranjem na poslu koje je uključivalo emocionalne i fizičke zdravstvene ishode kao što su depresivna raspoloženja i srčani simptomi. ${ }^{38}$ Način na koji se ljudi suočavaju sa stresom ima veću važnost za njihovo ukupno moralno, socijalno funkcioniranje i zdravlje nego broj i jači-

\footnotetext{
${ }^{33}$ Usp. Bi Ying HU i dr., The relation between school climate and preschool teacher stress. The mediating role of teachers' self-efficacy, Journal of Educational Administration, 57 (2019) 6, 748-767; DOI: 10.1108/JEA-08-2018-0146.

${ }^{34}$ Usp. Jill M. ALDRIDGE, Barry J. FRASER, Teachers' views of their school climate and its relationship with teacher self-efficacy and job satisfaction, Learning Environments Research, 19 (2016) 2, 291-307; DOI: 10.1007/s10984-015-9198-x.

${ }^{35}$ Usp. Brust Nemet, Velki, Some demographic, personal and class...; Collie, Shapka, Perry, School Climate and Social-Emotional Learning..., 1189.

${ }^{36}$ Usp. Maja BRUST NEMET, A correlation between teachers' social and pedagogical competences and school culture«, Sodobna Pedagogika/Journal of Contemporary Educational Studies, 69 (2018) 3, 142-155.

${ }^{37}$ Usp. Nichola SHACKLETON, Chris BONELL, Farah JAMAL, Elizabeth ALLEN, Anne MATHIOT, Diana ELBOURNE, Russell VINER, Teacher Burnout and Contextual and Compositional Elements of School Environment, Journal of School Health, 89 (2019) 12, 977 993. DOI: 10.1111/josh.12839.

${ }^{38}$ Usp. Burke, Greenglass, Schwarzer, Predicting teacher burnout..., 261.
} 
na samih stresnih epizoda. ${ }^{39}$ Stoga je potrebno pružiti učiteljima veću socijalnu podršku, više ih poticati na profesionalna usavršavanja te njegovati kolegijalne odnose da bi školska klima bila pozitivna i podržavajuća. Socijalna je podrška važna bez obzira na stresne događaje, stoga je nužno omogućiti učiteljima podržavajuće uvjete da bi se smanjivao učiteljev doživljaj stresa i povećavalo zadovoljstvo poslom jer će se na taj način učitelji znati nositi sa stresnim situacijama kada se one dogode. Postoje prijedlozi da se percipirana samoefikasnost u upravljanju razrednim odjelima uzima u obzir prilikom osmišljavanja intervencija za sprječavanje i liječenje izgaranja među učiteljima. ${ }^{40}$

Rezultati ovog istraživanja ukazuju da je potrebna proaktivna politika koja će poboljšati društveni status učitelja te implementacija sadržaja o upravljanju stresom tijekom studija i na stručnim formalnim i neformalnim usavršavanjima koja će prevenirati izgaranje učitelja na poslu. Učinkovitim i usmjerenim strategijama socijalne podrške, kao što su supervizije, socijalno-emocionalne radionice, radionice upravljanja stresom, strategije nošenja s problemima, nenasilnog rješavanja problema, upravljanje karijerom, kao i psihološka savjetovališta, omogućit će se učiteljima poticajno okruženje i poticajna školska klima. Učitelji će se osjećati bolje, samopouzdanije i zadovoljnije poslom, što bi moglo smanjiti stres među učiteljima te povećati zadovoljstvo i među učenicima, roditeljima, kao i ostalim dionicima uključenima u sustav odgoja i obrazovanja.

Jedna od glavnih prednosti provedenog istraživanja jest uključivanje učitelja iz svih regija Hrvatske. Također se ispituju različiti izvori stresa, a ne samo opći stres na poslu, što daje dublji uvid u problematiku s kojom se učitelji svakodnevno susreću. Ipak treba navesti i neke metodološke nedostatke. Prvenstveno se to odnosi na primjenu isključivo samoprocjene. Iako je za stres ključan subjektivni doživljaj, bilo bi dobro u budućim istraživanjima provjeriti i objektivne pokazatelje stresa, kao što su zdravstveno stanje, intenzitet kognitivnih i bihevioralnih simptoma prouzročenih stresom i slično. Također se preporuča da se školska klima mjeri na razini cijele škole, a ne samo na individualnoj, da bi se dobila objektivnija slika školske klime. Buduća istraživanja trebala bi provjeriti i odnos nekih drugih varijabli s različitim izvorima stresa, kao što su osobine ličnosti učitelja i općenito načini nošenja sa stresnom situacijom.

\footnotetext{
${ }^{39}$ Usp. Richard S. LAZARUS, Raymond LAUNIER, Stress-related transaction between person and environment, u: Lawrence PERVIN (ur.), Perspectives in interactional psychology, New York, Plenum, 1978, 287-327.

${ }^{40}$ Usp. André BROUWERS, Welko TOMIC, A longitudinal study of teacher burnout and perceived self-efficacy in classroom management, Teaching and Teacher Education, 16 (2000) 2, 239-253; DOI: 10.1016/S0742-051X(99)00057-8.
} 


\section{Zaključak}

Među hrvatskim učiteljima prevladava relativno visoka razina stresa, što može uzrokovati izgaranje na poslu. Značajne negativne posljedice izgaranja ne samo da djeluju na same učitelje, nego i na učenike, roditelje, kolege i cjelokupnu školsku klimu. Broj učenika u razrednom odjelu, školska klima i socijalna podrška pokazale su se značajnima za učiteljevu percepciju stresa. Učitelji koji rade $u$ razrednim odjelima $s$ više od dvadeset učenika te oni koji percipiraju školsku klimu negativnijom s manje socijalne podrške, doživljavaju i višu razinu stresa uzrokovanu radnim opterećenjem i potrebama za profesionalnim priznanjem. Iako je prosjek učenika u hrvatskim školama manji od dvadeset učenika po učitelju, očito je da još uvijek postoji nesrazmjer među pojedinim školama i njega bi trebalo ujednačiti. Učitelji smatraju da bi se podržavajućom klimom u školi i većom socijalnom podrškom smanjio i stres među učiteljima. Stoga se predlaže poticanje pozitivne kulture škole i produktivne školske klime karakterizirane otvorenim, kolegijalnim i demokratskim odnosima, poticanjem profesionalnog razvoja te predanost djelatnika jasno artikuliranom zajedničkom cilju. Potrebna je i proaktivna zaštita te u okviru formalnog i neformalnog učenja češće ponuditi učiteljima superviziju, socijalno-emocionalne radionice, radionice upravljanja stresom kao i radionice u kojima bi učili strategije nošenja s problemima. 


\section{Maja Brust Nemet* - Tena Velki*** \\ Relationship of Some Demographic and Class Characteristics and School Climate and Social Support to Teacher Stress \\ Summary}

Teacher stress is present in all schools, and teachers' demographic and class characteristics and school climate as well as social support are important for perceiving stress levels. The aim of the research was to examine the correlation between stress level and demographic and class characteristics, as well as school climate and social support among 311 Croatian classroom teachers. The teachers completed the Sources of teacher stress scale, the Social provisions scale, and the School climate survey, and provided demographic, class and school information. The results showed that demographic characteristics were not significant in relation to the level of stress, but of the class characteristics, the number of students in the class proved significant for the experience of stress. It was also found that teachers who experience higher level of total stress and higher level of stress caused by workload and need for professional recognition experience a more negative school climate, and higher level of stress is also associated with poorer social support.

Key words: school, school climate, social support, stress, teachers.

(na engl. prev. Una Šijan)

\footnotetext{
* Maja Brust Nemet, PhD, Assis. Prof., Josip Juraj Strossmayer University of Osijek, Faculty of Education; Address: Cara Hadrijana 10, HR-31000 Osijek, Croatia; E-mail: mbrust@foozos.hr.

**Tena Velki, PhD, Assoc. Prof., Josip Juraj Strossmayer University of Osijek, Faculty of Education; Address: Cara Hadrijana 10, HR-31000 Osijek, Croatia; E-mail: tvelki@foozos.hr.
} 